\title{
Analysis of Faculty Members Attitude towards Academic Development Endeavors in Some Selected Ethiopian Universities
}

\author{
Yilfashewa Seyoum \\ Asst. Prof., Curriculum Design and Development, Haramaya University, Ethiopia \\ yilfa2014@gmail.com
}

$$
\text { 列 }
$$

This article aims to analyse the attitudes of faculty members on how the current academic development programs were enacted in selected Ethiopian Universities. With the help of multiple cases design, evidence was gathered from faculty through attitude scale having a reliability index of 0.77 . Moreover, a document study including the day-to-day surveillance of the researcher's observations and colleague's reflections were also included. In the investigation, 250 cases have taken part. The findings of the study reassured that faculty members' predisposition on professional development programs to augment the level of educational activities was not aversive. The analysis of variance, F- test demonstrated that there were no significant differences among faculty members when gender and study sites had taken as variables. However, F-value was significant for years of experience. Moreover, less experienced and lower level qualified faculty members hold significantly favourable attitudes as compared to veteran and more qualified one. Overall, the study claims that universities should adapt options, and continue to use technologies as a means to bring faculty from different programs together and benefit from learning online.

Keywords: academics development, attitudes, faculty members, professional development and predisposition, members' attitudes

\section{INTRODUCTION}

Historically, professional development (PD) in teaching has not been seen as a priority for new academic staff in Higher Education. However, it is a cognizant fact that the provision of high quality teaching and learning is a key responsibility of the professionals who aim to develop standards for academic practices and continuing PD. According to Guskey (2002), the term PD is referred as the processes and activities premeditated to enhance the professional knowledge, capabilities and attitudes of academics in order to bring improvement on students' educational achievement. Villegas-Reimers (2003) viewed PD as a critical factor for ensuring quality education and an opportunity for instructors to augment their expertise.

Thus, when the goal is to increase students' learning and to improve instructors performance, academic development should be considered as a vehicle to materialize 
institutional reforms (Gordon, 2004; Smith \&Gillespie, 2007). Teacher educators and academic leaders agreed that success in the implementation of PD is a decisive input for promoting instructors' competencies and enhancing quality in education and training (Eccles \& Gootman, 2002).

In recent attempts, the series of Education Sector Development Programs (ESDP) [ESDP I, II, III and IV] of Ethiopia have created opportunities to produce trained and skilled human power at all levels as a driving force in the process of promoting culture, effecting social transformation and bringing economic development of the country (MoE, 2005). More importantly, while all the policy documents contend the centrality of teachers for promoting learning, the emphasis on improving teachers' quality and teachers' development is most stressed in the 2005, ESDP III. In this document, the Ministry of Education has given priority for continuous PD assuming that it is the right of teachers as well as of a great value for national development. This intention ought to bring about change in educational attainment (Mosha, 2006).

Meanwhile, considering the need for PD in Ethiopian universities, UNESCO was one of the responsible organizations to cooperate with the higher education institutions toward the fulfillment of the policy demand. The creation of a National Pedagogical Resource Centre (NPRC) was one of the mechanisms where the Institute of Educational Research, Addis Ababa University in cooperation with UNESCO and IICBA had actively participated (Amareet al., 2000). In June 2007, the Ministry produced two important documents, School Improvement Package and A Blue Print for Ethiopian Teachers Development Program. The purpose of these documents was to emphasis on the indispensability of PDP and bolster varied academic programs. Similarly, in January 2009, a new Framework for Continuous PD of Teachers, School Leaders and Educators in Ethiopia was developed (MoE, 2009). The former guideline was criticized on the ground that it was a top-down approach that ignored the interests of faculty members and institutions to share their views and critical concerns.

This study, therefore, targeted to investigate faculty members' attitudes on how the existing practice of PD was enacted to support the activities of teaching and learning. The study can be viewed as illuminative for identifying and analysing one of the core problems of academics predisposition in the implementation of PD initiatives. Accordingly, considering the researcher's first-hand experience in coordinating staff development programs at Haramaya University, the topic has been identified as an important area of investigation for the clarification of weak spots, the discovery of opportunities and exploring the situation of PD in the context of our education system in general and the university's academic development settings in particular.

\section{Professional Development in the Ethiopian University Context}

In Ethiopia, the PDPs established at various higher education institutions was set to accomplish two major targets: improving academic staff professional competencies and supporting the academic programs for keeping quality of students learning (HERQA, 2007). However, Cantrell's (2009) study noted that various factors found to jeopardize the long-term future of PD centers. Chief amongst these were staff mobility, lack of 
career and incentive structures, lack of physical facilities for PD centers and insufficient recognition for those actually attending academic development program courses. On his part, Wessonu (2009) contends that while training through the various PD centers was found to be useful for ensuring quality, its sustainability and effectiveness are hampered by limitations of coverage, organizational capacity, resources and leadership.

Experiences indicated that from time to time and year to year, although it seems that there was quantitative progress in PD deliberations, there was no recognized and context related implementation policy that guides and governs the activities of PD and there was no formalized, integrated and continuous system to check whether the quality of such training is up to the expected level or not. Recent studies in the area of PD focused principally on the brief workshops carried at the end of a given training or about specific types of centre/program (e.g. ADRC or HDP) in action (Anto, 2006, \&Aytaged, 2012). Moreover, since the provision of PD is at infantile level, investigating participants' predisposition on the implementation practices have not been profoundly investigated. To this end, this study was planned to attain the following objectives:

i. Examine the intensity and magnitude of faculty attitude towards the current professional development programs in Haramaya University.

ii. Determine the extent and dynamics of academics satisfaction on the existing professional development endeavors.

iii. Analyze whether there are significant mean differences in the respondents attitudes when specific attributes as sex, experience in teaching and study Sites are taken into account.

\section{REVIEW OF LITERATURE}

\section{Faculty Members Perceptions, Commitment and Active Participation in PDP}

The commitment, attitudes, and competency patterns of faculties which are supposed to benefit from the PDPs contribute as crucial group of factors for implementation. Academics are constant factor in the education system and thus have a key role for classroom innovation (Pearson, 2008). An innovation usually involves some skeptical reaction. Such discrepancies between claims of the innovation and acceptance by instructors may be important starting points for further development (Fullan, 2007).

To implement an innovation means for the practitioners involved in a long-term commitment to practice the innovation. In this regard, Komba and Nkumbi (2008) in their research pointed out that the academics should perceive PD as being important for implementing innovations, as it improves them professionally, academically and technically to help them adjust to the new thinking. However, most respondents think that it is inadequately supported and motivated. At all levels (system, university, department), PD is poorly coordinated and scarcely budgeted for. In the context of Ethiopia, the study conducted by Anto (2006) specifies that a great number of instructors do not have curiosity to participate in the highly relevant university PDPs. Lack of pedagogical competencies of the university instructors, lack of commitment from management and some academic staff, lack of transparent leadership, and resources to run the activities were some of the deficits for PD trainings. 


\section{Teachers' Satisfaction}

The success of education is dependent on the quality of workforce in teaching. Thus, there should be an effort to improve, practitioners' knowledge, skills and confidence through PD (Fullan, 2007). While the purpose of PD is improving teaching' competencies and students' achievement, the personal satisfaction of instructors with PD implementation is one of the emotional issues to be emphasized and highly valued (Hergraves, 2003). In practice, instructors' satisfaction with PD is not the same in every area, always and at every level of the education structure (Gordon, 2004). In this regard, the study conducted by Gray (2006) discovered that:

Most teachers were satisfied with their PD over the last decades. Negative feelings were especially associated with 'one size fits all' standardized PD provision, which did not take account of teachers' existing knowledge, experience and needs. Practitioners felt that the principal drivers for PD activity over the last 10 years had been national priorities and these had taken precedence over individual needs. Attitudes to PD were shaped by complex interrelationships between local, cultural factors, teachers' career stage and subject affiliations.

Meanwhile, in an investigation conducted by King (2004), the levels of academics' satisfaction with PD were fairly low and to him only training related to whole-school strategies satisfied more than half of the sample. Training related to government initiatives scored among the lowest. Despite their comparative lack of satisfaction with what was on offer, most of those questioned felt that PD was important and relevant to their teaching. Last but not least, Minale's (2006) study on PD revealed that:

Instructors claimed that they have acquired new knowledge and skills as a result of the training. Above all, the training has enhanced their knowledge about learning styles, student centered teaching, continuous assessment, and collaborative learning. Trainees reported that they were satisfied with the methods of training and skills of HDP leaders. However, they noted that HDP was an ambitious reform initiative that did not consider actual classroom situations and problems. Respondents commented that the level of organizational support to the training, lack of reward, scarcity of resources, and classroom lay out were critical issues.

From the summary of the above studies, it can be inferred that academics satisfaction needs to be the most important achievement and consideration in the deliberation of PD practices. The above studies strongly suggested that even well designed PD training may not satisfy instructors unless the PD training practices meet the need and interest of beneficiaries. Thus, a careful follow up that assess the level of satisfaction and perception of instructors on PD Endeavour need to be highly valued and enacted.

\section{METHOD}

In choosing the research method, usually three conditions are considered. The kind of research question posed, the degree of control an investigator has over actual behavioral events, and the extent of focus on contemporary events (Creswell, 2009). Within these conditions, a case study was preferred. Meanwhile, in selecting the audience of this 
study, simple random, and stratified sampling methods were considered. Similarly, using purposeful sampling four PD coordinators and program leaders and eight academic leaders who were involved in the implementation of HDP were placed as important informants of this study.

To measure the attitudes of instructors toward the existing PD trainings, an attitude and satisfaction scales were developed. Using Cronbach alpha, the internal consistency reliability coefficient was determined and found as 0.77 . Furthermore, on the basis of measured data (facts, opinions and emotions obtained through questionnaires), parametric statistical tests as Analysis of Variance, Z-test, and Paired sample t-test for quantitative analyses are employed. In qualitative data analyses, thematic description, narrative and interpretative approaches were employed.

\section{RESULTS AND DISCUSSION}

\section{Adama University}

Respondents' Attitudes toward the PD Trainings

Table 1: Overall Attitudes of Instructors Toward the PD Trainings

\begin{tabular}{llllllll}
\multicolumn{2}{l}{ Unfavorable Attitude } & \multicolumn{2}{l}{ Indifferent Attitude } & Favorable Attitude & Mean & SD \\
\hline In No. & In \% & In No. & In \% & In No. & In \% & 50.0 & 6.8 \\
\hline 115 & 95.8 & 1 & 0.8 & 4 & 3.4 & & \\
\hline
\end{tabular}

Table 1 depicted the quantitative score regarding the attitudes of respondents and revealed that only 3.4 percent of the respondents reacted favorably and 0.8 percent of them were found to have indifferent attitudes toward the PD practices in place. The rest, almost the majority of the respondents (95.8 percent), indicate that they hold unfavorable attitudes toward the PD training currently in practice. Moreover, the mean score, that is, 50.0 which was inclined toward the direction of negative attitudes, confirmed the possession of adverse attitudes by majority of the respondents. The standard deviation suggests how the magnitude of the score of the respondents spread in the distribution. A moderate variation within the respondents' attitudes toward the instructors' PD initiatives was the trends of this research finding.

In an interview conducted at Adama University, one senior lecturer expressed what he thinks about the existing PD training experience together with his colleagues.

In a week, we have two days and two hours in each day to come together to deal with Higher Diploma Program (HDP). Because we were not feeling good in the training program, we had a unique name for HDP. We call it a "Health Damaging Program". We were considering it as something "alone and frightened" (BB: December, 2013)

These reflections suggest that although faculty believes in the indispensability of PD, in practice, they have unfavorable predispositions. The interview offered by the above participant also verified that some faculty members' feeling toward the current practice was not encouraging. This can necessitate revisiting of the present practices critically. 
Faculty Members' Attitudes toward the PD Trainings with Respect to Respondents Attributes: Sex, Teaching Experience and College/Schools

In order to analyze the attitudes with the respondents characteristics(sex, academic rank, teaching experience and school setting), a one-way analysis of variance was computed and presented as shown in the succeeding tables.

Table 2: The mean difference in attitudes with sex as the respondents' variable

\begin{tabular}{lllllll}
\hline Source of variations & Sum of Squares & Df & Mean Square & $F$ & Sig. \\
\hline \multirow{3}{*}{ Sex } & Between Groups & .23 & 1 & .23 & .01 & .95 \\
\cline { 2 - 7 } & Within Groups & 5633.77 & 118 & 47.74 & & \\
\cline { 2 - 7 } & Total & 5634.00 & 119 & & & \\
\hline
\end{tabular}

From table 2, it can be inferred that there is no significant mean difference in the attitudes of faculty members depending on their sex. This means, respondents uniformly favoured is favour the current PD practice irrespective of their sex as an attribute.

Table 3: The mean difference in attitudes with teaching experience as variable

\begin{tabular}{lllllll}
\hline Source of variations & Sum of Squares & $D f$ & Mean Square & $F$ & Sig. \\
\hline Teaching & Between Groups & 417.52 & 2 & 208.76 & 4.50 & .02 \\
\cline { 2 - 7 } Experience & Within Groups & 5424.35 & 117 & 46.36 & & \\
\cline { 2 - 7 } & Total & 5839.87 & 119 & & & \\
\hline
\end{tabular}

Here, $\mathrm{F}$ value is significant. Meaning, respondents vary in their response when the variable teaching experience is considered. Furthermore, the post-hoc analysis of variance assured that faculty with fewer experience in teaching have better attitudes toward the PD training than more experienced one. Studies in the field of PD verified that the amount of formal education and teaching experience could have relation to teacher change. In their study of 100 teachers and the change they demonstrated after participating in varied PD, Smith and Hofer (2003) identified that those teachers with fewer years of experience and with low level of education changed more.

Table 4: The mean difference in attitudes with school as the respondents' variable

\begin{tabular}{lllllll}
\hline Source of variations & Sum of Squares & $D f$ & Mean Square & $F$ & Sig. \\
\hline \multirow{3}{*}{ College } & Between Groups & 597.52 & 5 & 119.51 & 2.71 & .024 \\
\cline { 2 - 7 } & Within Groups & 5036.48 & 114 & 44.18 & & \\
\cline { 2 - 7 } & Total & 5634.00 & 119 & & & \\
\hline
\end{tabular}

Table 4 shows that F-value is significant when the variable school is considered. Further computation of the post-hoc analysis of variance (Tukey Test) identified that staff members in the school of engineering and pedagogy have significantly higher attitudes than other. The possible reason for this could be that school of engineering is the oldest and the most experienced and had exposure with many kinds of training in general and instructors' PD practices in particular. Similarly, since the school of pedagogy 
instructors have better orientation to PD than other schools; this could be the grounds for the possession of positive attitudes toward the PD practices.

\section{Respondents' Satisfaction on the Professional Development Efforts}

In table 5, the overall score was 3.00, indicating that most academics were satisfied with their PD experience $(\mathrm{N}=120)$. On the other hand, although some respondents recognized the importance of keeping on top of new development through PD initiatives, they unfavorably felt that PD had least impact on their promotion prospects.

Table 5: Teachers' satisfaction with professional development over the last 5 years

\begin{tabular}{lcccccc}
\hline & $N$ & Minimum & Maximum & Mean & SD & Aggregate mean \\
\hline $\begin{array}{l}\text { Your professional } \\
\text { development }\end{array}$ & 120 & .00 & 5.00 & 2.98 & 1.06 & 3.00 \\
\hline Your promotion prospects & 120 & .00 & 5.00 & 2.25 & 1.20 & \\
\hline Your teaching skills & 120 & .00 & 5.00 & 3.22 & 1.10 & 1.06 \\
\hline $\begin{array}{l}\text { Your self-confidence/self- } \\
\text { esteem }\end{array}$ & 120 & .00 & 5.00 & 3.23 & 1.19 \\
\hline Your desire to learn more & 120 & .00 & 5.00 & 3.34 & 1.09 \\
\hline Students' learning outcomes & 120 & .00 & 5.00 & 3.20 & 1.09 \\
\hline Your leadership skills & 120 & .00 & 5.00 & 2.79 & 1.23 \\
\hline
\end{tabular}

Moreover, PD had demonstrated less effect on leadership skills than on the development of teaching strategies and students' learning outcomes and this showed in the teachers' desire for more PD concern with improving leadership and management skills. As a whole, the PD initiative has significant effect on instructors: the desire to learn more, their teaching skills, and empower their self-esteem. However, although the above sectors seem higher than the average value, with regard to their promotion prospects, academics seem dissatisfied. Moreover, instructors' involvement in developing leadership skills was not deliberated as other dimensions of the PD plan. Recent research by Steinert (2008) suggested that the content of PD should encompass the empowerment of instructors' leadership and management skills in some ways.

\section{Haramaya University}

Respondents' Attitudes toward the PD Trainings

Table 6: Respondents attitudes towards PD trainings

\begin{tabular}{|c|c|c|c|c|c|c|c|}
\hline \multicolumn{2}{|c|}{ Unfavorable attitude } & \multicolumn{2}{|c|}{ Indifferent attitude } & \multicolumn{2}{|c|}{ Favorable attitude } & \multirow{2}{*}{$\begin{array}{l}\text { Mean } \\
49.05 \\
\end{array}$} & \multirow{2}{*}{$\begin{array}{r}S D \\
7.05 \\
\end{array}$} \\
\hline In No. & In \% & In No. & In $\%$ & In No. & In $\%$ & & \\
\hline 119 & 97.5 & 0 & 0 & 3 & 2.5 & & \\
\hline
\end{tabular}

Table 6 reveals that only 2.5 percent of the respondents reacted favorably and none of them found to have indifferent attitudes toward the PD practices in place. The rest, almost the majority of the respondents ( 97.5 percent), reacted that they have unfavorable attitudes toward the PD training. The mean score, which is 49.05 , is inclined toward the direction of negative attitudes, which also indicates the possession of unfavorable 
attitudes by majority of the respondents. The standard deviation of the total score of the attitudes of respondents indicates slight variation among the informants of this study. In relation to this, Mosha (2006) concluded that academics' motivation is the most important of all factors that affect practitioners' attitude and commitment for PD activities. For PD to be effective, the instructor has to perceive it positively. So, PD is an inherent process and is strongly connected to the practitioners' desire and attitude for growth and change.

Faculty Members' Attitudes toward the PD Trainings with Respect Respondents Attributes: Sex, Teaching Experience and College/Schools

Table 7: The mean difference in attitudes with respondents' sex as variable

\begin{tabular}{lllllll}
\hline & Source of variations & Sum of squares & $d f$ & Mean square & $F$ & Sig. \\
\hline \multirow{3}{*}{ Sex } & Between Groups & 37.43 & 1 & 37.43 & .75 & .39 \\
\cline { 2 - 7 } & Within Groups & 5984.28 & 120 & 49.87 & & \\
\cline { 2 - 7 } & Total & 6021.71 & 121 & & & \\
\hline
\end{tabular}

Results in table 7 evidently show that the calculated F-value for sex is not significant at 0.05 level. It means that the respondents' reaction to the PD training is identical for both faculty members in terms of sex distribution.

Table 8: The mean difference in attitudes when teaching experience taken as a variable

\begin{tabular}{lllllll}
\hline Source of variations & Sum of squares & $d f$ & Mean square & $F$ & Sig. \\
\hline \multirow{2}{*}{$\begin{array}{l}\text { Experience } \\
\text { in teaching }\end{array}$} & Between Groups & 422.41 & 2 & 211.21 & 5.00 & .01 \\
\cline { 2 - 7 } & Within Groups & 5538.52 & 119 & 42.16 & & \\
\cline { 2 - 7 } & Total & 5960.93 & 120 & & & \\
\hline
\end{tabular}

Table 8 clearly demonstrated that F-value for teaching experience is significant. It means that respondents with different level of experience have different attitudes toward the PD training in place. The post-hoc analysis of variance further demonstrated that faculty with less experience in teaching have more score in attitudes than medium and highly experienced ones. This result is consistent with the findings conducted by Smith and Gillespie (2007). The study emphasized the following individual characteristics as influencing how much, and in what ways, faculty changed after participating in PD: (a) years of experience-instructors with fewer years of experience changed more (b) venue of first teaching experience-instructors who began their teaching career changed more and(c) level of education- instructors with a bachelor's degree or less changed more.

Table 9: The mean difference in attitudes when college is taken as a variable

\begin{tabular}{lllllll}
\hline Source of variations & Sum of squares & $d f$ & Mean square & $F$ & Sig. \\
\hline \multirow{3}{*}{ College } & Between Groups & 160.18 & 9 & 17.80 & .34 & .96 \\
\cline { 2 - 7 } & Within Groups & 5861.53 & 112 & 52.34 & & \\
\cline { 2 - 7 } & Total & 6021.71 & 121 & & & \\
\hline
\end{tabular}


In the case of Haramaya University, the unique experience of respondents of various colleges did not bring difference in the attitudes of respondents. It means that respondents consistently expressed their feeling irrespective of their college milieu. Studies in the field of PD, however, stressed that attitudes toward PD is shaped by complex interrelationships between local and cultural factors, teachers' career stage, and subject affiliations (King, 2004\&Mosha, 2006)). In this case, although the college of agriculture has relatively long experience in teaching, research and extension services than other colleges, this has not brought difference in the responses of faculty members. Similarly, although it is assumed that members in the college of education and behavioural sciences have more acquaintance of the PD practices; this didn't demonstrate any change in the attitudes.

\section{Respondents' Satisfaction on the Professional Development Efforts}

Table 10: Instructors' satisfaction of the PD milieu over the last 5 years

\begin{tabular}{|c|c|c|c|c|c|c|}
\hline & $N$ & Minimum & Maximum & Mean & $S D$ & Aggregate mean \\
\hline $\begin{array}{l}\text { Your professional } \\
\text { development }\end{array}$ & 122 & .00 & 5.00 & 2.63 & 1.48 & 2.86 \\
\hline Your promotion prospects & 122 & .00 & 5.00 & 2.23 & 1.59 & \\
\hline Your teaching skills & 122 & .00 & 5.00 & 2.95 & 1.47 & \\
\hline $\begin{array}{l}\text { Your self-confidence/self- } \\
\text { esteem }\end{array}$ & 122 & .00 & 5.00 & 3.09 & 1.59 & \\
\hline Your desire to learn more & 122 & .00 & 5.00 & 3.21 & 1.62 & \\
\hline Students' learning outcomes & 122 & .00 & 5.00 & 2.87 & 1.49 & \\
\hline Your leadership skills & 122 & .00 & 5.00 & 2.71 & 1.52 & \\
\hline
\end{tabular}

As table 10 clearly demonstrated, the overall score is 2.86 indicating that most instructors were satisfied than dissatisfied with their PD experience $(\mathrm{n}=122)$. The table further revealed that although other sectors seem higher than the average value, with regard to their promotion prospects, instructors seem relatively dissatisfied. Moreover, improvement in developing leadership skills is not carried out as other dimensions of the PD plan. This result indicates that although the majority of the respondents have unfavorable attitudes toward the planned PD training, once they involved, they acquired interest in the activities and contents of PD trainings.

\section{Cross-Case Analysis}

\section{Instructors' Attitudes toward the PD Trainings}

With the attitude scale developed, the participants were asked to show the extent of their agreement or disagreement with the relevant statement on a 5-point scale from 5 for 'strongly agree' to 1 for 'strongly disagree' depending on the type of items, being negative or positive statements. And, in the analysis of the attitudes of respondents in the two study sites, it was found that the majority of the respondents have negative attitudes (95.8 percent in $\mathrm{AU}$ and 97.5 percent for $\mathrm{HU}$ ). The following figure demonstrates the attitudes of respondents in the study sites. 


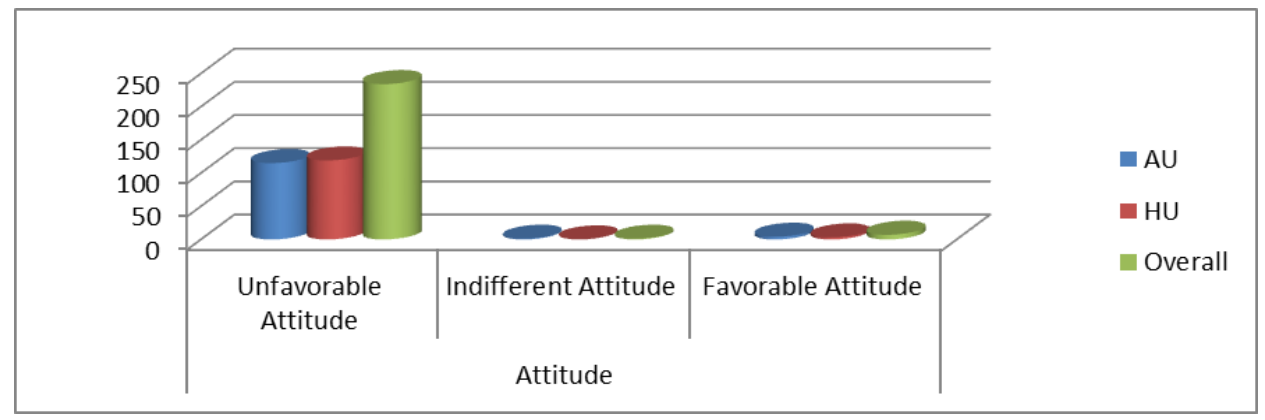

Figure 1: Summary of instructors' attitudes toward the PD trainings

The exceeding figure clearly disclosed that only 2.9 percent of the respondents reacted favorably and 0.4 of them found to have indifferent attitudes toward the PD in practice. The rest, almost the majority of the respondents (96.7 percent) reacted that they have unfavorable attitudes toward the PD training. The mean score, which is 49.5 , seems to round toward the direction of negative attitudes, which also indicates the possession of unfavorable attitudes by majority of the respondents. The standard deviation of the total score of the attitudes of respondents was calculated and is equal to 6.97. This indicates how the magnitude of the score of the respondents' spread in the distribution. Slight variation in attitudes toward instructors' PD initiatives is the trends of the research findings at hand. In general, there is a significant mean difference in the attitudes of respondents between AU and HU. Meanwhile, other experience outside of Ethiopia is also revealed the same findings. Accordingly, Guskey(2002) found that educators themselves frequently regard PD as having little impact on their day-to-day responsibilities. Some even consider it as a waste of their time. Trainees participate in PD primarily because of contractual obligations but often see it as something they must 'get out of the way' so that they can get back to the important work of educating students.

Meanwhile, previous researches on PD clearly put it that an instructor who perceives PD positively is eager to attain new knowledge, skills, values, and dispositions. Within such dispositions, there is pride, self-esteem, team spirit, commitment, drive, adventure, creativity, and vision (Mosha, 2006). Thus, all these attributes have to be owned by the instructor; and perceptions depend on self-evaluation, the support of institutional leadership, and institutional culture (Smith and Hofer, 2003).

Faculty Members' Attitudes toward the PD Trainings with Respect Respondents Attributes: Sex, Teaching Experience and Locality/University

Table 11: The mean difference in attitude of respondents with respect to the variable sex

\begin{tabular}{|c|c|c|c|c|c|c|}
\hline \multicolumn{2}{|c|}{ Sources of variations } & \multirow{2}{*}{$\begin{array}{l}\text { Sum of squares } \\
22.46\end{array}$} & \multirow{2}{*}{$\frac{d f}{1}$} & \multirow{2}{*}{$\begin{array}{l}\text { Mean square } \\
22.46\end{array}$} & \multirow{2}{*}{$\begin{array}{l}F \\
(\mathrm{AU}) .01 \\
\end{array}$} & \multirow[t]{2}{*}{ Sig. } \\
\hline \multirow{3}{*}{ Sex } & Between Groups & & & & & \\
\hline & Within Groups & 11687.94 & 240 & 48.70 & $\mathrm{HU}(.75)$ & \\
\hline & Total & 11710.40 & 241 & & 0verall, .46 & .50 \\
\hline
\end{tabular}


When the respondents score presented in combined manner, table 11 demonstrated that F was not significant for sex. This result is the same in the two study sites observed separately. Overall, respondents have the same attitude toward the training irrespective of their gender differences.

Table 12: The mean difference in attitudes of respondents with respect to the variable teaching experience

\begin{tabular}{llllllll}
\hline & \multicolumn{2}{c}{ Source of variations } & Sum of squares & Mf & Mean square & $F$ & Sig. \\
\hline $\begin{array}{l}\text { Experience in } \\
\text { teaching }\end{array}$ & Between Groups & 266.38 & 2 & 133.19 & Overall, 2.60 & .049 \\
\cline { 2 - 8 } & Within Groups & 11834.24 & 239 & 49.52 & (AU)4.51 & \\
\cline { 2 - 8 } & Total & 11901.04 & 241 & & HU(5.00) & \\
\hline
\end{tabular}

Table 12 depicted that F-value was significant for years of experience in attitudes toward the PD practices. It means unlike sex and academic rank variables, teaching experience significantly brought differences in attitudes of respondents. Meanwhile, the post hoc analysis of variance indicated that younger and less experienced instructors have better attitudes than older and experienced instructors. With almost consistent result, other research has shown that older, male, instructors tended toward more negative attitudes toward PD. However, here younger and novice instructors in particular, again presented a more positive picture (Hirsh, 2009).

Table 13: The mean difference in attitudes of respondents with respect to study sites

\begin{tabular}{|c|c|c|c|c|c|c|}
\hline \multicolumn{2}{|c|}{ Sources of variations } & \multicolumn{2}{|c|}{ Sum of squares $d f$} & \multirow{2}{*}{$\begin{array}{l}\text { Mean square } \\
54.69\end{array}$} & \multirow{2}{*}{$\begin{array}{l}F \\
1.13 \\
\end{array}$} & \multirow{2}{*}{$\begin{array}{l}\text { Sig. } \\
.29\end{array}$} \\
\hline University & Between Groups & 54.69 & 1 & & & \\
\hline & Within Groups & 11655.71 & 240 & 48.57 & & \\
\hline & Total & 11710.40 & 241 & & & \\
\hline
\end{tabular}

The combined data verified that respondents' attitudes were the same across the study sites; since F-value is insignificant across university treatment. This refers to the condition that PD is almost in the same position for the two universities. Although the universities have varied experience in the latest centre/ program (PSISC and PGDHET) training, they are the same in HDP and ADRC. More importantly, the only PD framework has been training that actively and austerely enacted. This resemblance in both institutions may bring respondents to have identical attitudes toward the implementation of PD in place. Overall, in all the three attributes of the respondents: sex, academic rank, teaching experience, the attitudes of respondents was steady across the two study sites.

\section{Instructors' Level of Satisfaction on PD Practices}

Respondents' level of satisfaction on the current practice was also examined as indicator of effective implementation of PD. Instructors were required to tick a box on a Likert type question which ranged from $1=$ a very little extent to $5=$ a very great extent. The score of respondents has shown in table 14. 
Table 14: Teachers' satisfaction with professional development

\begin{tabular}{lllllll}
\hline & $N$ & Mean $(A U)$ & Mean $(H U)$ & Mean $(T)$ & $S D$ & T-values \\
\hline Your professional development & 242 & 2.9750 & 2.6311 & 2.8017 & 1.30190 & Not Sig. \\
\hline Your promotion prospects & 242 & 2.2500 & 2.2295 & 2.2397 & 1.40848 & Not Sig. \\
\hline Your teaching skills & 242 & 3.2167 & 2.9508 & 3.0826 & 1.30487 & Not Sig. \\
\hline $\begin{array}{l}\text { Your self-confidence/self- } \\
\text { esteem }\end{array}$ & 242 & 3.2333 & 3.0902 & 3.1612 & 1.35229 & Not Sig. \\
\hline Your desire to learn more & 242 & 3.3417 & 3.2131 & 3.2769 & 1.42365 & Not Sig. \\
\hline Students' learning outcomes & 242 & 3.2000 & 2.8689 & 3.0331 & 1.31971 & Not Sig. \\
\hline Your leadership skills & 242 & 2.7917 & 2.7131 & 2.7521 & 1.38325 & Not Sig. \\
\hline
\end{tabular}

Overall Mean Score $=2.90$

The respondents were asked how much satisfied they had been with their PD experience over the last 5 years. The overall score is found to be 2.9 , indicating that most instructors are happy with the PD experience. In conjunction with such a finding, it was also realized that except for their promotion prospects, in all other aspects, respondents felt a sense of satisfaction. It can easily be traced that respondents' attitudes to PD training was unfavorable. However, once the respondents involved in the training, through time, recognizing its applicability, they develop interest in it. In connection to this, Livneh and Livneh (1999) argued that two motivational factors predicted participation: high internal motivation and external motivation to learn.

Table 14 further demonstrated that instructors' improvement in developing leadership skills was not carried out as other dimensions of the PD plan. PD is important because of its potential impact on the sustainability of the youth development workforce. Training coordinators and facilitators who have PD opportunities reported feeling of more confident and more satisfied with their jobs. It is believed that these outcomes could lead to a better staff retention and lower turnover rates. It is important to emphasize the possibility; however, staff retention may improve only if academics that have training opportunities also have opportunities for increased responsibility and higher compensation (Livneh \& Livneh, 1999).

On the other hand, in respect of overall result of respondent's satisfaction, although the mean value of $\mathrm{AU}$ is greater than $\mathrm{HU}$, this result is not significant. Briefly, respondents were satisfied irrespective of their university academic development settings.

\section{CONCLUSIONS}

Generally, instructors' predisposition on the principles and practices of PDPs to augment the level of educational activities is positive. Nevertheless, in quantitative analysis, only 2.9 percent of the respondents reacted favorably and 0.4 of them were found to have indifferent attitudes toward the PD practices. The rest, almost the majority of the respondents ( 96.7 percent), reacted that they have unfavorable attitudes toward the existing PD practices. The analysis of variance, F- test demonstrated that there are no significance mean differences among sex and study sites with regard to attitudes 
toward the PD practices. However, F-value is significant for years of experience. Less experienced and qualified instructors hold significantly favorable attitudes when compared to experienced and more qualified faculty members.

Moreover, except in the area of leadership and promotional prospects, most instructors are satisfied with the contributions of PD experience. Instructors preferred dominantly to spend their time on PD activities in order to improve their teaching skills and subject knowledge. More importantly, respondents insisted that the major reason why they were involved in the various PDPs resulted from the need for institutional development plan and national priorities, than individual instructors' needs and curiosity. As a result, instructors' involvement in planning and enacting the PD initiatives is either less regarded or totally neglected.

\section{IMPLICATIONS FOR PRACTICES AND FUTURE RESEARCHES}

It is believed that education has to be goal oriented and should be linked to the pressing need of the society, the principle strictly adhered by the philosophy of pragmatism. Pragmatism adhere knowledge and values, and the method of determining these must not be stiff and stagnant. Pragmatism supports the principle of dynamism and utility. Thus, knowledge for faculty professional growth should not be ready made and must not be relegated behind the scene without deliberation. Similarly, the values in our case are knowledge that is applicable to solve our real problem (e.g. education quality). Again, the intensity and magnitude of a problem could vary from place to place that require some form of flexibility in terms of content and methods. By the same contention, the PD plan and practices in place require a form of flexibility since it is affected by contextual factors. Hence, the design and implementation of professional development entails vigilant reference to local circumstances.

Secondly, as research indicates that faculty perceptions, attitudes and working conditions (e.g. adequate time for academic deliberation) influence the effectiveness of professional development programs, further and thorough research is required on the optimal configuration of faculty working conditions, program structure, preparation time, job benefits, working hours, and time for training and their relation to staff quality, student achievement, and decline of attrition rate. As there are modest or no research on many of these conditions, this could be one area of special importance. We also need researches comparing the outcomes of participating in job-embedded and traditional form of professional development 'packages' so that policymakers and professional developers have good information on which to base decisions about what formats of training and under which conditions to offer .

Finally, universities should adapt and continue to use technologies as methods to bring faculty from different programs together for professional development and to participate in learning online. Such facilities would allow faculty members to have access to wide range of philosophies, practices and challenges in their profession. In addition, online materials promote faculty's professional learning autonomy by freeing them technical as well as substantive restrictions that commonly affect the depth and width of practitioners' learning opportunities. However, professional development planners need 
to ensure that collegiality can still be an essential feature of the online of such a professional development program. As a result, future research should focus on exploring more on the use of online learning for PDPs with collegiality and collaboration in focus.

\section{REFERENCES}

Amare A., Daniel D. \&Wanna L.(2000).Establishing the national resource center.In Proceeding of the National Conference, AAU, August 11-12, 2000, Institute of Educational Research.

Anto A. (2006). Teacher professional development practices of Arbaminch University, Ethiopia: An exploration of the present status.(Unpublished Master's Thesis). Faculty of Behavioural Sciences, University of Twente, Enschede.

Aytaged S. (2012). Continuous professional development program for higher education academics in Ethiopia. Views, perceived needed competencies and organization in focus. Greener Journal of Educational Research, 2(3): 27-41.

Cantrell, M. (2009).Assessment of risk for the sustainability of staff development centers in Ethiopian Universities. Unpublished Document.

Creswell, J. (2009). Research design: Qualitative, quantitative, and mixed methods approaches $\left(3^{\text {rd }}\right.$ ed.). Los Angeles: Sage Publications.

Fullan, M. (2007). Change the terms for teacher learning. Journal of Staff Development, 28(3): 35-36.

Gordon, S. (2004). Professional development for school improvement: Empowering learning communities. Boston: Pearson Education.

Gray, S. (2006). An enquiry into continuing professional development for teachers. London: Esmee Fairburn Foundation.

Guskey, T. (2002). Professional development and teacher change: Teachers and teaching. Theory and Practice, 8(2): 381-390.

Hargreaves, A. (2003). Teaching in the knowledge society: Education in the age of insecurity. New York: Teachers College Press.

HERQA (2007).Areas of focus for institutional quality audits.Publication Series009. Addis Ababa, Ethiopia.

Hirsh, S. (2009).A New Definition. Journal of Staff Development, 30(4): 10-16.

King, H. (2004).Continuing professional development in higher education: What Do academics do? Planet, 13: 26-29.

Komba L., Willy \& Emmanuel N. (2008).Teacher professional development in Tanzania: Perceptions and practices. Journal of International Cooperation in Education, 11(3): 67-83.

Livneh, C., \&Livneh, H. (1999). Continuing professional education among educators: Predictions of participation in learning activities. Adult Education Quarterly, 49: 91106. 
Minale A. (2006).Evaluating professional development of teacher educators in Ethiopia: A Case study of the higher diploma program at Addis Ababa University.(Unpublished Master's Thesis).University of Twente, Enschede.

MoE (2009).A new framework of continuous professional development for teachers, school leaders and educators in Ethiopia.Addis Ababa, Ethiopia.

MoE (2005). The federal democratic republic of Ethiopia education sector development program III. Addis Ababa, Ethiopia.

Mosha, H. (2006). Capacity of school management for teacher professional development in Tanzania. The Role of Universities in Promoting Basic Education in Tanzania. Millenium Towers Hotel, Dar es Salaam, Tanzania.

Payne, E. (2010).Implementing walkthroughs: One School's Journey. Unpublished, PhD Dissertation, Virginia Polytechnic Institute and State University.

Smith, C., \& Gillespie, M. (2007).How teachers change: A study of professional development in adult education. Boston: National Center for the Study of Adult Learning and Literacy.

Smith, C.\& Hofer, J. (2003).The characteristics and concerns of adult basic education teachers. Boston: Center for the Study of Adult Learning and Literacy.

Solomon A.(2008). Policy formulation, curriculum development, and implementation in Ethiopia. Addis Ababa: AAU Book Center.

Steinert, Y. (2008). Faculty development-A brief introduction. Downloadedfromwww.amee.org/.../Introduction \%20to\%20Medical\%20Education\%20$\% 20$ Steinert

Villegas-Reimers, E. (2003). Teachers professional development: An International Review of Literature. Retrieved from: http://www.unesco.org/iiep.

WossenuYimam.(2009). Quality of higher education in Ethiopian public institutions. Addis Ababa: Forum for Social Studies.

\section{Turkish Abstract}

Bazı Seçilen Etiyopya Üniversitelerindeki Akademik Gelişim Çabalarına Karşı Fakülte Üyelerinin Tutumlarının Analizi

$\mathrm{Bu}$ makale fakülte üyelerinin bazı seçilen Etiyopya Üniversitelerindeki mevcut yürürlükteki akademik geliştirme programlarına olan tutumlarını analiz etmeyi amaçlamaktadır. Çoklu vaka deseninin aracılığıyla 0.77 güvenirlik katsayısı olan tutum ölçeğiyle veriler öğretim kadrosundan toplanmıştır. Dahası, araştırmacının gözlemlerinin ve meslektaşların yansıtıcı dönüşlerinin günlük incelemesini içeren bir döküman çalışması da dahil edilmiştir. Araştırmada 250 vaka dahil edilmiştir. Çalışmanın bulguları fakülte üyelerinin eğitim aktivitelerinin seviyesini artırmak için profesyonel gelişim programlarına olan eğilimlerinin itici olmadı̆̆ını ortaya çıkardı. Varyans analizi, F-testi cinsiyet ve çalışma alanı değişken olarak alındığında anlamlı bir farklılığın olmadığını göstermiş̧tir. Fakat, kıdem değişkeni için F-değeri anlamlıdır. Ayrıca, daha az deneyimli ve daha düşük ünvanlı öğretim üyeleri deneyimlilere göre anlamlı lehte tutumlar 
göstermişlerdir. Genel olarak, çalışma üniversitelerin farklı programlardan öğretim üyelerini biraraya getirmek ve online öğrenmeden faydalanmak için opsiyonlar uygulamasını, teknolojiler kullanmasını önermektedir.

Anahtar Kelimeler: akademik gelişim, tutum, öğretim üyeleri, profesyonel gelişim ve eğilim

\section{French Abstract}

\section{Analyse d'Attitude de Membres de Faculté vers Efforts de Développement Universitaires dans quelques Universités éthiopiennes Choisies}

Cet article vise à analyser les attitudes des membres de faculté comment les programmes de développement universitaires actuels ont été ordonnés dans des Universités éthiopiennes choisies. Avec l'aide de design d'affaires multiple, l'évidence a été rassemblée de la faculté à l'échelle d'attitude ayant un index de fiabilité de 0.77. De plus, une étude de document incluant la surveillance quotidienne des observations du chercheur et les reflets du collègue a été aussi incluse. Dans l'enquête, 250 affaires ont participé. Les découvertes de l'étude ont rassuré que la prédisposition des membres de faculté sur des programmes de développement professionnels pour augmenter le niveau d'activités éducatives n'était pas aversive.L'analyse des variations, F-le test démontré qu'il n'y avait aucune différence significative parmi des membres de faculté quand le genre et des sites d'étude avaient pris comme des variables. Cependant, la F-valeur était significative pendant les années d'expérience. De plus, le niveau moins expérimenté et inférieur a qualifié la prise de membres de faculté des attitudes significativement favorables en comparaison du vétéran et plus qualifié. En général l'étude revendique que les universités devraient adapter des options et continuer à utiliser des technologies comme un moyen pour apporter la faculté de programmes différents ensemble et l'avantage d'apprendre en ligne.

Mots Clés: développement d'universitaires, attitudes, membres de faculté, développement professionnel et prédisposition, attitude

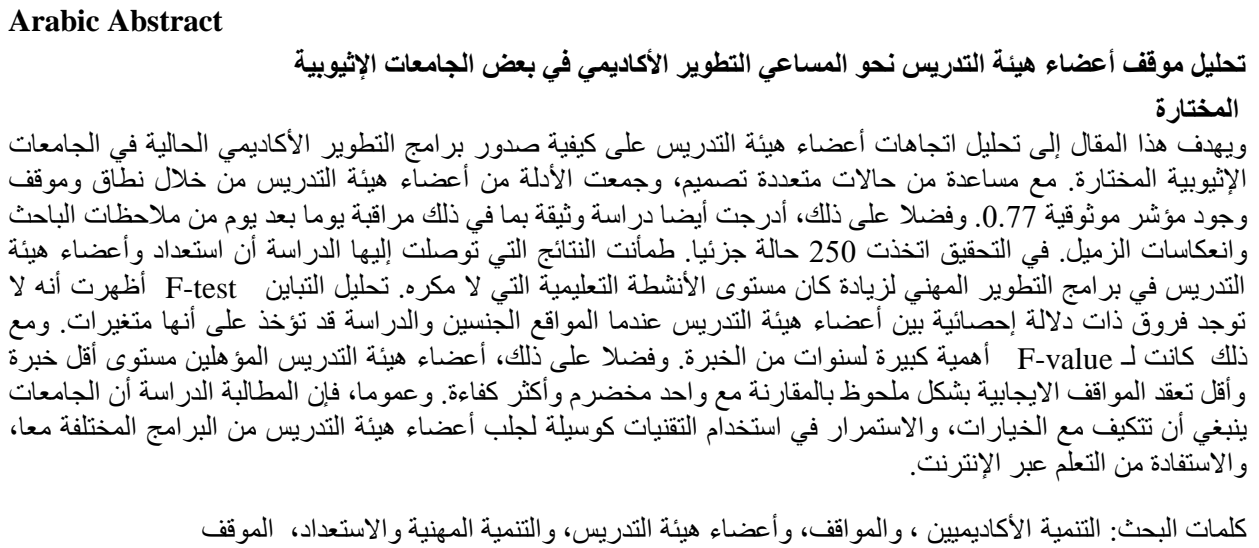

